\title{
Untreated Hematopoietic and Lymphoid Cell Neoplasm
}

National Cancer Institute

\section{Source}

National Cancer Institute. Untreated Hematopoietic and Lymphoid Cell Neoplasm. NCI

Thesaurus. Code C115907.

A finding of hematopoietic or lymphoid cell neoplasm that has not been treated. 